\title{
Koperasi Swadaya Untuk Meningkatkan Aktivitas Ekonomi dan Kesejahteraan Warga Dusun Parit Panjang Desa Jambi Tulo
}

\author{
Pratiwi Indah Sari ${ }^{1}$, Redi Indra Yudha ${ }^{2}$ \\ ${ }^{1}$ Fakultas Keguruan dan Ilmu Pendidikan, Universitas Batanghari \\ ${ }^{2}$ Fakultas Keguruan dan Ilmu Pendidikan, Universitas Batanghari \\ Correspondence Email: pradasari676@gmail.com¹, ilcapitanoredi@gmail.com²
}

\begin{abstract}
Abstrak. Koperasi semata-mata bertujuan untuk meningkatkan taraf hidup, baik dalam hal ekonomi maupun sosial para anggota maupun pengguna koperasi. Warga Dusun Parit Panjang Desa Jambi Tulo aktivitas perekonomian hanya tergantung pada hasil perkebunan, atau menjadi buruh yang bekerja pada salah perusahaan sehingga cenderung terlibat dengan para tengkulak atau rentenir apabila kekurangan modal maupun uang untuk memenuhi kebutuhan sehari-hari. Para warga memiliki keinginan untuk mendirikan sebuah lembaga koperasi yang lebih baik bercermin dari kegagalan sebelumnya. Dengan demikian, dapat dikatakan bahwa keinginan tidak dapat merubah suatu kondisi ataupun keadaan apabila tidak didukung dengan wawasan dan pengetahuan, disamping terdapat dasar hukum dalam mengatur sebuah kegiatan atau aktivitas ekonomi yang berhubungan dengan kesejahteraan masyarakat banyak.
\end{abstract}

Kata Kunci: Koperasi, Ekonomi, Kesejahteraan Masyarakat

\begin{abstract}
Cooperatives are solely aimed at improving the standard of living, both in terms of economic and social aspects of the members and users of cooperatives. Residents of Dusun Parit Panjang, Jambi Tulo Village, economic activity only depends on plantation products, or become laborers who work for one company so they tend to get involved with middlemen or moneylenders if they lack capital or money to meet their daily needs. The residents have a desire to establish a cooperative institution that is better reflected on the previous failure. Thus, it can be said that the desire cannot change a condition or situation if it is not supported by insight and knowledge, besides there is a legal basis in regulating an activity or economic activity related to the welfare of the community at large.
\end{abstract}

Keyword: Cooperative, Economy, Community Welfare

\section{PENDAHULUAN}

Masyarakat merupakan suatu kumpulan yang terdiri dari berbagai unsur, yakni suku, ras, dan agama. Namun, itu semua hanya sebagai ciri khas dan pembeda agar setiap individu tidak kehilangan jati diri mereka tanpa melupakan solidaritas dalam kehidupan bermasyarakat, berbangsa, dan bernegara. Oleh sebab itu, kehidupan bermasyarakat seharusnya dapat menjadi salah satu faktor dalam daya dorong pertumbuhan baik dari sisi pendidikan, sosial, dan ekonomi. Hal ini dimaksudkan untuk menciptakan sebuah kehidupan masyarakat yang madani, dan secara tidak langsung akan mendorong pertumbuhan ekonomi dalam sebuah daerah.

Berdasarkan kutipan Undang-Undang Nomor 25 tahun 1992 pasal 1, ayat (1) dan (2), koperasi dipandang sebagai organisasi ekonomi dan sosial yang memiliki tujuan akhir dalam meningkatkan kesejahteraan para anggota dan masyarakat sekitar, serta memberikan sumbangan mendasar kepada pembangunan dan pertumbuhan sosial ekonomi masyarakat di pedesaan dengan berlandaskan asas kekeluargaan dan gotong royong. Maka, diharapkan dengan adanya koperasi dapat menghimpun kekuatan guna mengatasi berbagai hambatan struktural, membuka akses kepada pasar, modal, informasi, teknologi, mengoptimalkan potensi, dan memanfaatkan peluang usaha yang ada dipedesaan.

Dusun Parit Panjang, Desa Jambi Tulo, Kecamatan Maro Sebo, Kabupaten Muaro Jambi ditempati oleh masyarakat yang kehidupannya hanya ditunjang dari sektor pertanian, dengan komoditas utama dan rata-rata cenderung bercocok tanam sayur-sayuran. Hal ini diduga dengan dengan kondisi geografis yang cocok untuk bercocok tanam. Meskipun demikian, ada juga yang memiliki kebun kelapa sawit, dan karet sendiri. Dimana, hasil-hasil pertanian tersebut bukan saja untuk dikonsumsi sendiri untuk memenuhi kebutuhan sehari-hari melainkan juga dikirim ke Kota Jambi maupun daerah sekitar kepada pedagang sayuran yang ada di pasar-pasar tradisional.

Di Dusun Parit Panjang, Desa Jambi Tulo, Kecamatan Maro Sebo, Kabupaten Muaro Jambi sebelumnya telah didirikan Kelompok Usaha Tani. Meskipun Kelompok Usaha Tani tersebut dapat melaksanakan studi banding ke 
Pratiwi Indah Sari dan Redi Indra Yudha, Koperasi Swadaya Untuk Meningkatkan Aktivitas Ekonomi dan Kesejahteraan Warga Dusun Parit Panjang Desa Jambi Tulo

Pekanbaru (Riau) dan Bukit Tinggi terkait permasalahan pertanian dan kelompok tani, organisasi tersebut tidak dapat bertahan lama karena tidak adanya rasa kebersamaan dan saling percaya terutama kepada pimpinan Kelompok Usaha Tani. Pada akhirnya, sebelum pimpinan tersebut meninggal, Kelompok Usaha Tani di Dusun Parit Panjang, Desa Jambi Tulo, Kecamatan Maro Sebo, Kabupaten Muaro jambi dibubarkan.

Informasi lain yang penulis terima dari salah satu penduduk yang tinggal di sana, diketahui bahwa kegagalan dalam membangun Kelompok Tani tersebut karena tidak adanya rasa kepercayaan dalam hal manajemen organisasi Kelompok Tani antara ketua, anggota, serta masyarakat sekitar sebagai pengguna tanpa ada keterangan secara rinci. Meskipun demikian, dari keterangan tersebut setidaknya diberikan pemahaman bahwa manajemen organisasi sangat penting dalam menjalankan sebuah organisasi. Hal ini didukung juga dengan informasi bahwa secara keseluruhan masyarakat yang ada Dusun Parit Panjang, Desa Jambi Tulo, Kecamatan Maro Sebo, Kabupaten Muaro jambi hanya lulusan jenjang pendidikan SD.

Berdasarkan beberapa uraian dalam analisis situasi di atas, maka peneliti ingin memberikan solusi dalam menumbuhkembangkan potensi masyarakat, serta membantu dalam memberikan sarana penanaman modal secara tidak langsung dengan sistem dari masyarakat untuk masyarakat. Sebab, cenderung permasalahan yang dihadapi oleh masyarakat di Dusun Parit Panjang, Desa Jambi Tulo, Kecamatan Maro Sebo, Kabupaten Muaro Jambi adalah kurangnya modal dalam mengembangkan usaha yang mereka tekuni.

\section{LANDASAN TEORI}

Ekonomi pedesaan merupakan suatu kegiatan masyarakat dalam mengembangkan sistem perekonomian desa. Desa adalah kesatuan masyarakat hukum yang memiliki batas-batas wilayah yursdiksi, berwanang untuk mengatur dan mengurus kepentingan masyarakat setempat. ${ }^{5}$

Dalam sistem ekonomi pedesaan akan selalu dihadapkan dengan suatu permasalahan ekonomi itu sendiri, yang mana permasalahn ini bertujuan untuk mendapatkan suatu kemakmuran, adapun yang menjadi permasalah ekonomi di suatu daerah adalah dapat dilihat secara umum, yakni sebagai berikut:

1. Masalah produksi adalah suatu permasalahan bagaimana memproduksisemua benda yang di butuhkan oleh banyak orang. Dan produksi disini adalah untuk memenuhi kebutuhan masyarakat secara umum.

2. Masalah distribusi, setelah suatu benda di produksi permaslahan ayang akan muncul di ekonomi desa adalah bagaimana benda hasil produksi tersebut dapat ketempat konsumen yang membutuhkan, distribusi adalah suatu transaksi langsung anatara produsen dengan konsumen atau melalui transaksi dipasar.

3. Masalah konsumsi, yang menjadi suatu permasalahan dalam konsumsiadalah bagaimana benda hasil produksi dapat dimanfaatkan secara nyata dan dimiliki oleh konsumen, barang yang di produksi harus sesuai dengan kebutuhan seseorang sehingga barang tersebut dapat di gunakan oleh orang yang membutuhkan.

Dalam kehidupan di desa akan muncul suatu usaha-usaha desa, yang diantaranya:

a) Mendirikan perusahaan

Perusahaan atau produsen disebut juga rumah tangga produksi, perusahaan adalah kelompok anggota masyarakat yang tugasnya memproduksi barang dan jasa untuk memnuhi kebutuhan masyarakat

b) Mendirikan koperasi desa

Koperasi adalah badan usaha yang beranggotakan orang-orang atau badan hukum koperasi yang berlandaskan kegiatannya berdasarkan prinsip koperasi sekaligus sebagai gerakan ekonomi rakyat yang berdasar atas asaskekeluargaan.

c) Mengadakan pasar

Pasar merupakan tempat berkumpulny masyarakat desa untuk melakukan suatu transaksi jual beli, dalam pasar ini terjadi kegiatan distribusi dan konsumsi yang terjadi antara pedagang dengan masyarakat. 
Pratiwi Indah Sari dan Redi Indra Yudha, Koperasi Swadaya Untuk Meningkatkan Aktivitas Ekonomi dan Kesejahteraan Warga Dusun Parit Panjang Desa Jambi Tulo

Ilmu ekonomi adalah ilmu yang mempelajari prilakau manusia alam meilih dan menciptakan kemakmuran, maka ekonomi merupakan suatu pengetahuan yang membahasa masalah di dalam keluarga untuk mendapatkan suatu kenyamanan dalam keluarga.

Ilmu ekonomi adalah studi tentang prilaku masyarakat dalam menggunakan sumber daya yang langka dalam memperoduksi kordinitas, untuk kemudahan menyalurkannya kepada berbagai individu dan kelompok yang ada dalam suatu masyarakat.

Menurut Wahyu dkk mengatakan ekonomi adalah ilmu yang mempelajari mengenai sumber daya terbatas untuk memenuhi kebutuhan manusia yang tak terbatas, setiap manusia membutuhkan makanan, minuman, hiburan dann lain sebagainya.

Kegiatan ekonomi adalah kegiatan yang dilakukan manusia untuk memperoleh barang dan jasa dan untuk mencapai kemakmuran hidupnya.Kegiatan ekonomi ada 3 yaitu produksi, konsumsi dan distribusi.

Produksi adalah kegiatan menghasilkan atau menambah nilai guna barang atau jasa untuk memenuhi kebutuhan. Tujuan Produksi adalah : Secara umum: memenuhi kebutuhan manusia untuk mencapai kemakmuran. Secara khusus: dilihat dari kepentingan pihak produsn dan konsumen. Dari pihak produsen: untuk meningkatkan keuntungan serta menjaga kesinambungan kehidupan perusahaan. Dari pihak konsumen: untuk menyediakan berbagai benda pemuas kebutuhan.

Konsumsi adalah kegiatan menghabiskan atau mengurangi nilai guna suatu barang baik sekaligus maupun berangsur-angsur, contoh : makan,minum, memakai baju, memakai komputer dan sebagainya. Tujuan Konsumsi yaitu Kegiatan untuk memenuhi kebutuhan hidup.

Distribusi adalah kegiatan menyalurkan barang atau jasa dari produsen ke konsumen. contoh : kegiatan perdagangan di pasar, toko, minimarket, pelabuhan, dll. Tujuan Distribusi adalah Untuk menyampaikan barang ataujasa dari tempat produsen ke tempat pengguna atau pemakai.

\section{METODE PENELITIAN}

Sebelum kegiatan pengabdian pada masyarakat dilakukan, terlebih dahulu dilakukan penjajakan lokasi. Setelah dilakukan serangkaian penjajakan, maka ditetapkan Dusun Parit Panjang, Desa Jambi Tulo. Materi yang disajikan sebagai berikut: 1) Penyuluhan tentang filosofi, teori, dan praktek kegiatan administrasi dan operasional, dan 2) Pemberian analisa terkait bagaimana menguasai cara praktis dan kiat sukses menjalankan koperasi. Selain itu, warga masyarakat diajak langsung berdiskusi tentang perkoperasian dan unit-unit usaha yang dapat dibentuk didalamnya. Adapun metode yang digunakan dalam kegiatan pengabdian pada masyarakat ini adalah :

1. Metode andragogi, yaitu setelah para warga dikumpulkan, materi disampaikan melalui ceramah dengan materi yang telah ditetapkan.

2. Mengadakan demonstrasi seperlunya.

3. Mengadakan diskusi, tanya jawab atau bertukar pengalaman dalam memecahkan suatu masalah.

Sementara, tahap akhir dari kegiatan di lapangan adalah mengevaluasi kegiatan yang bertujuan untuk mengetahui tingkat adopsi para warga masyarakat terhadap materi yang disampaikan atau seberapa besar respon warga masyarakat Dusun Parit Panjang, Desa Jambi Tulo terhadap kesinambungan penyuluhan pada masa yang akan datang.

\section{HASIL DAN PEMBAHASAN}

\section{Perancangan Sturuktural Organisasi Koperasi}

Berdasarkan hasil pengamatan di lapangan, diperoleh informasi bahwa cenderung para warga masih minim pengetahuan terkait struktural organisasi pada badan usaha seperti koperasi, dan cenderung para warga masyarakat Dusun Parit Panjang, Desa Jambi Tulo memiliki pemahaman bahwa koperasi sama dengan badan usaha swadaya lain, seperti kelompok usaha tani. Maka, perancangan struktural ini sangat diperlukan sebagai langkah awal agar masyarakat yang ada dan telah cukup lama tidak mengikuti kegiatan-kegiatan yang ada dalam sebuah organisasi, selain kurangnya pemahaman mereka sehingga pembagian tugas dan penempatan orang yang tepat disamping adanya beberapa pembahasan lain yang perlu diperhatikan harus benar-benar dikaji secara lebih mendalam.

"Penerapan struktur pengendalian manajemen yang meliputi struktur organisasi, pendelegasian wewenang dan tanggung jawab, serta pusat pertanggungjawaban yang diterapkan Koperasi Simpan Pinjam Ayamen Mandiri Kombi telah efektif." (Senduk, dkk., 2016:892). Dengan demikian, struktural sebuah organisasi akan memiliki peran dalam 
Pratiwi Indah Sari dan Redi Indra Yudha, Koperasi Swadaya Untuk Meningkatkan Aktivitas Ekonomi dan Kesejahteraan Warga Dusun Parit Panjang Desa Jambi Tulo

mengatur dan mengawasi berbagai kegiatan pelaksanaan baik administrasi maupun operasional, maka perlu diperhatikan desain, rancangan, serta konsep yang akan diterapkan dalam sebuah organisasi yang akan dibentuk maupun untuk merubah menuju perbaikan sistem apabila organisasi tersebut telah berjalan dalam beberapa waktu lamanya.

\section{Pelatihan Manajemen Organisasi Koperasi}

Adapun bahan kajian dalam pelatihan ini sendiri meliputi berbagai aspek pengembangan manajemen yang perlu diperhatikan dalam sebuah koperasi, seperti merubah struktur kerja tanpa meninggalkan jati diri koperasi itu sendiri, pembagian tugas dan tanggungjawab yang harus dimiliki setiap anggota, rumusan jangka pendek dan jangka panjang, proses dan sistem keuangan berdasarkan kebutuhan masa sekarang, fokus RAT dan SHU, dan yang terakhir adalah pengembangan konsep capaian koperasi setiap tahun demi kemajuan anggota pada umumnya dan koperasi pada khususnya.

"Pelatihan pembukuan dan manajemen koperasi untuk menambah peluang bisnis yang sehat dan juga dapat mensejahterakan masyarakat. Pelatihan pembukuan dan manajemen koperasi dapat memberikan wawasan dan pengetahuan bagi pengurus dan anggota koperasi tentang fungsi manajemen dan pembukuan koperasi yang benar". (Heryati, dkk., 2017:43)

Dengan demikian, pelatihan manajemen diberikan agar dapat menambah wawasan dan pemahaman bagi para masyarakat yang akan menjadi pengelola sekaligus pengurus koperasi, sehingga di masa yang akan datang dapat meminimalisir permasalahan yang terjadi sekecil mungkin tanpa harus merusak sistem dan partisipasi para anggota lainnya. Sebab, koperasi memiliki dasar dan landasan berdasarkan asas kekeluargaan sehingga setidaknya dengan adanya penerapan manajemen organisasi dalam koperasi menuju arah yang lebih baik, diharapkan mampu mengembangkan inovasi dan kreasi para anggota itu sendiri demi kemajuan koperasi tersebut.

\section{Pelatihan Penggunaan Jasa Simpan Pinjam Dengan Sistem Kredit}

Pelatihan ini akan memberikan sebuah pembelajaran bagi masyarakat agar tidak hanya bergantung pada simpanan yang ada, sebab apabila dalam kurun waktu yang relatif singkat ada beberapa anggota yang mau meminjam modal sementara dana yang tersedia sangat minim disertai dengan persentase yang kecil, selain ketidakjelasan laporan mengenai perihal peminjaman tersebut. Maka, pelatihan ini akan memberikan gambaran kepada masyarakat bagaimana mengelola jasa peminjaman modal dengan menggunakan sistem kredit tanpa merugikan para anggota koperasi nantinya. Dimana, pelatihan ini akan berisi mengenai beberapa materi seperti apa itu kredit, untuk apa kredit ada dalam koperasi, bagaimana mengelola kredit demi kemajuan anggota dan koperasi, serta pengembangan kredit dalam memajukan tingkat pendapatan dan kesejahteraan hidup para masyarakat yang menjadi anggota koperasi.

\section{KESIMPULAN}

Peneliti ingin memberikan solusi dalam menumbuhkembangkan potensi masyarakat, serta membantu dalam memberikan sarana penanaman modal secara tidak langsung dengan sistem dari masyarakat untuk masyarakat. Sebab, cenderung permasalahan yang dihadapi oleh masyarakat di Dusun Parit Panjang, Desa Jambi Tulo, Kecamatan Maro Sebo, Kabupaten Muaro Jambi adalah kurangnya modal dalam mengembangkan usaha yang mereka tekuni.

Penulis menyarankan untuk mendirikan sebuah koperasi sebagai awal mula perkembangan ekonomi dan pada masa yang akan datang akan mendorong timbulnya industri rumah tangga/UMKM sejenis di kalangan masyarakat setempat. Dimana, dalam tahap perencanaan kegiatan tersebut akan dilakukan melalui tahap penyuluhan akan pentingnya koperasi, dan secara langsung juga akan melakukan pendampingan sementara sehingga masyarakat benarbenar mampu dan memahami tentang koperasi.

\section{DAFTAR PUSTAKA \\ Dari Kepres \\ Undang-Undang Nomor 25 Tahun 1992 tentang Perkoperasian.}

\section{Dari Jurnal}

Heryati, Agustina \& Fauzia Afriyani. 2017. Pelatihan Pembukuan dan Manajemen Koperasi Bagi Pengurus Koperasi SMPN 26 Kota Palembang. Jurnal Abdimas Mandiri, 1 (1), 41-45.

Senduk, F. Angelia., Hendrik Manossoh., \& Dhullo Affandi. 2016. Analisis Penerapan Sistem Pengendalian Manajemen Pada Koperasi Simpan Pinjam “Ayamen Mandiri” Kombi, Jurnal EMBA, 4(4), 885-892. 
Pratiwi Indah Sari dan Redi Indra Yudha, Koperasi Swadaya Untuk Meningkatkan Aktivitas Ekonomi dan Kesejahteraan Warga Dusun Parit Panjang Desa Jambi Tulo 